\title{
Correlation of Vit D3 and serum ferritin levels in anemic patients in a hospital based study.
}

1. MBBS, M.Phil, DCH, MPH Associate Professor Hematology Nowshera Medical College, Nowshera Pakistan.

2. MBBS, M.Phil

Assistant Professor Pathology Nowshera Medical College, Nowshera Pakistan

Correspondence Address: Dr. Hamzullah Khan Department of Hematology Director Research \& Development Nowshera Medical College, Nowshera Pakistan.

hamzakmc@gmail.com

Article received on: 07/05/2020

Accepted for publication: $25 / 07 / 2020$

\begin{abstract}
Hamzullah Khan ${ }^{1}$, Mohammad Basharat ${ }^{2}$
ABSTRACT... Objectives: To determine the correlation of Vit D3 levels with serum ferritin in patients with anemia. Study Design: Cross Sectional study. Setting: Department of Pathology, Qazi Hussain Ahmed Medical Complex Nowshera. Period: $5^{\text {th }}$ Jan 2019 to $31^{\text {st }}$ Dec 2020. Material \& Methods: Data entered in SPSS $25^{\text {th }}$ version. Descriptive statistics was used for numerical variables. Pearson correlation was used for correlation of Vit D3 with serum ferritin levels. Normality of data was checked by Shapiro wilk test. Mann Whitney $U$ test was used to show the difference of Vit D3 and ferritin levels in gender. Results: The total of 192 anemic patients with $\mathrm{Hb}<10 \mathrm{~g} / \mathrm{dl}$ as per definition of $\mathrm{WHO}^{1}$ were referred for ferritin level estimation with $142(74 \%)$ females and $50(26 \%)$ males. Out of total, 47 were also advised with Vit D3 level estimation with $29(61.7 \%)$ females and $18(38.3 \%)$ males. Mean with standard deviation for age was $30+9.6$ years. Mean with standard Error of mean of Vit D3 was (Mean-15.5ng/ml, SE 2.19). Mean with standard Error of mean of serum ferritin was (Mean-48.2ng/ml, SE 5.90). We observed $35(74.5 \%)$ cases out of 47 , as Vit D3 deficient with a count less than $20 \mathrm{ng} / \mathrm{ml}$. We observed that $118(61.5 \%)$ were iron deficient with serum ferritin less than $15 \mathrm{ng} / \mathrm{ml}$. Person correlation showed a statistically significant correlation of Vit D3 with ferritin $(p=0.022, r=0.7)$. Spearman ranked correlation showed a statistically significant correlation between the categories of Vit D3 and ferritin $(p=0.022, r=0.7)$. Mann Whitney $U$ Test showed no significant difference in gender groups for botht the variables ( $p=0.86 \& p=0.33$ respectively) thus retain the null hypotheses. Conclusion: The frequency of deficiency Vit D3<20ng/ml in anemic patients was $74 \%$ while that of ferritin $<15 \mathrm{ng} / \mathrm{ml}$ in anemic patients was $61.5 \%$. There is a strong statistically significant correlation of Vit D3 with serum ferritin in anemic patients with $\mathrm{Hb}<11 \mathrm{~g} / \mathrm{dl}$.
\end{abstract}

Key words: $\quad$ Correlation Statistics, Serum Ferritin, Vit D3.

Article Citation: Khan H, Basharat M. Correlation of Vit D3 and serum ferritin levels in anemic patients in a hospital based study. Professional Med J 2020; 27(11):23762382. https://doi.org/10.29309/TPMJ/2020.27.11.4771

\section{INTRODUCTION}

Vitamin D3 also called sunshine vitamin, is a fat soluble vitamin than increase the absorption of calcium, magnesium and phosphate in the intestine. In human its variant D3 and D2 are existing as vital compounds. ${ }^{1}$

Vit D3 deficiency is prevalent worldwide affecting more than a billion population globally. Vit $D$ deficiency can result in progression of Osteoporosis, rickets and osteomalacia. ${ }^{2}$

Beside the appreciable sun light in Pakistan still the burden of Vit D3 deficiency is highly alarming and devastating the nation both on health ground as well as a threat to economy.
So for so after searching the literature we failed to find the researchers to have assessed vitamin $\mathrm{D}$ deficiency across all age and gender groups.

Vitamin D deficiency in Pakistan is reportedly endemic in nature and is more commonly reported in children, women and elderly population. ${ }^{3}$ The more dangerous than that is that Vit D3 deficiency is undermined, under-diagnosed and under-treated among the dietary insufficiencies worldwide ${ }^{4,5}$ this includes Pakistan as well as a nation. ${ }^{6}$

In past its role in regard with calcium absorption was mainly on focus but in recent era its additional functions like its role in prevention of 
cardiovascular disease and anemia are under discussion in literature. ${ }^{7}$

On the other hand Ferritin is a protein which stores iron, and indicates the iron storage / reservoir in the body. The depletion/exhaustion of these stores can lead to sever IDA. Ferritin is the main storage form of iron, therefore is the best indicator for assessment of iron deficiency. ${ }^{8}$ The determination of serum ferritin by in-vitro is done to assess body iron stores. In adulthood ferritin concentration is directly related to the iron storage in the body. Serum ferritin concentration has the highest sensitivity and specificity to detect iron deficiency as reported in the literature. ${ }^{9}$

Studies have reported a strong correlation between the Vit D3 and serum ferritin levels and their contribution in co-morbidities associated with their deficiencies. A study reported that vitamin D was positively associated with serum ferritin levels with a $(p=0.041) .{ }^{10}$ In terms of anemia, specially the Iron deficiency anemia, literature has reported that there is a positive correlation of Vit D3 with serum ferritn levels. ${ }^{11,12}$

Another study reported that there was a strong relationship of Vit D3 deficiency and decreased iron store as sole risk factors for chronic neck pain. ${ }^{13}$ They further correlated it with female gender being more exposed to neck pain when presented with hypovitminosis and decreased ferritin.

Therefore the present study was designed as to ascertain the correlation of Vit D3 levels with serum ferritin in anemic patients in our population.

\section{MATERIAL \& METHODS}

This cross sectional study was conducted in the department of Pathology, Qazi Hussain Ahmed Medical Complex Nowshera from $5^{\text {th }}$ Jan 2019 to $31^{\text {st }}$ Dec 2020.

Ethical committee Nowshera Medical College approval was taken before execution of study via notification no. 78/NMC/ERB, Dated: 07-01-2019.

Inclusion criteria were all anemic patients as per WHO criteria ${ }^{1}$ with $\mathrm{HB}<11 \mathrm{~g} / \mathrm{dl}$, referred to pathology laboratory of Qazi Hussian Ahmed Medical Complex Nowhsera for Vit D3 and serum ferritin levels irrespective of age and gender.

Exclusion criteria were patients with Vit D supplementation. Similarly all candidates taking oral or IV iron therapy for their already diagnosed IDA were also excluded. Patients with request of serum ferritin or Vit D3 with $\mathrm{Hb}>11 \mathrm{~g} / \mathrm{dl}$ were also excluded from the study.

About $2 \mathrm{ml}$ blood was drawn from each individual, by veni-puncture under aseptic condition. Blood in Gel bottles was stored for serum ferritin and Vit D3 analysis. Then blood was centrifuged. Serum Vit D3 was measured by electro-chemiluminescence immunoassay using Roche Cobas E411 Chemistry Analyzer for which commercial kits of Roche diagnostics were used as per the instructions of the manufacturer.

Patients were categorized on the basis of Vit D3 levels as follow,

1. Vit D3 Deficient $=$ Vit D3 (less than $20 \mathrm{ng} / \mathrm{ml}$ )

2. Vit D3 Insufficient=Vit D3 (20.1-29.9ng/ml)

3. Vit D3 Sufficient $=$ Vit D3 $(>30 \mathrm{ng} / \mathrm{ml})$

We followed the laid down criteria of $\mathrm{Hb}$ is less than $11 \mathrm{~g} / \mathrm{dl}$ as per WHO recoommedations. ${ }^{14} \mathrm{We}$ received $90 \%$ patients form gynecology OPD and indoor patients.

We categorized our patients in three categories on the basis of serum ferritin levels. Analysis of serum ferritin levels based on the recommendations of the WHO. ${ }^{15}$

1. IDA: less than $15 \mathrm{ng} / \mathrm{ml}$

2. Normal or otherwise: $>150 \mathrm{ng} / \mathrm{ml}$

Data entered in SPSS $25^{\text {th }}$ version. Descriptive statistics was used for numerical variables like age, vit D3 level, ferritin levels and gender. Normality of data check by Shapiro wilk test.

Pearson correlation was used for correlation of Vit D3 with serum ferritin levels. Spearman 
ranked correlation test was performed to see the correlation of categories of Vit D3 with Categories of Serum ferritin. Man Whitney $U$ test was used for skewed data to show the difference of Vit D3 and serum ferritin levels in gender groups.

\section{RESULTS}

The total no of patients under trial were 192 who were referred for ferritin level estimation with $142(74 \%)$ females and $50(26 \%)$ males. Out of 192 , 47 were also advised the Vit D3 level estimation with $29(61.7 \%)$ females and $18(38.3 \%)$ males. (Table-I).

The descriptive statistics of age with Mean plus standard deviation was $30+9.6$ years. Minimum age was 18 months to a maximum of 70 years. Mean with standard Error of mean of Vit D3 was (Mean-15.5ng/ml, SE 2.19) with minimum of 3ng/ $\mathrm{ml}$ to maximum of $70 \mathrm{ng} / \mathrm{ml}$. Mean with standard Error of mean of serum ferritin was (Mean-48.2ng/ $\mathrm{ml}$, SE 5.90), with minimum of $1.72 \mathrm{ng} / \mathrm{ml}$ to maximum of $438.6 \mathrm{ng} / \mathrm{ml}$ as recorded in our study population. (Table-II)

We categorized patients referred for Vit D3 estimation into three categories. ${ }^{17}$

1. Vit D3 Deficient =Vit D3 (less than $20 \mathrm{ng} / \mathrm{ml}$ )

2. Vit D3 Insufficient=Vit D3 $(20.1-29.9 \mathrm{ng} / \mathrm{ml})$

3. Vit D3 Sufficient $=$ Vit D3 $(>30 \mathrm{ng} / \mathrm{ml})$

It was noticed that $35(74.5 \%)$ were Vit D3 deficient with less than $20 \mathrm{ng} / \mathrm{ml}$ and $7(14.9 \%)$ as Vit D3 insufficient with Vit D3 in range of $20.1-29.9 \mathrm{ng} / \mathrm{ml}$. Only $5(10.6 \%)$ were having normal Vit D3 levels. (Table-III)
We categorized our patients in three categories on the basis of serum ferritin levels. Analysis of serum ferritin levels based on the recommendations of the $\mathrm{WHO}{ }^{10}$

Iron Deficiency Anemia: less than $15 \mathrm{ng} / \mathrm{ml}$

We observed that 118 (61.5\%) were iron deficient (serum ferritin less than $15 \mathrm{ng} / \mathrm{ml}$ ). (Table-IV)

Person correlation test was performed to see the correlation of Vit D3 levels with Serum ferritin levels and it was observed that a statistically significant strong uphill positive correlation was seen between the levels of Vit D3 with Serum ferritin with $(p=0.022, r-0.7)$. (Table-V)

To dig out further Spearman ranked correlation test was performed to see the correlation of categories of Vit D3 with Categories of Serum ferritin as mentioned in table3 \&4, and it was observed that a statistically significant strong uphill positive correlation was seen between the categories of Vit D3 with Categories of Serum ferritin with $(p=0.022, r-0.7)$. (Table-VI)

Using Shapiro Wilk test to see the distribution of data. It was observed that data was distributed in skewed manner in both Vit D3and ferritin variables with significant $p=0.001$. (Table-VIla)

Mann Whitney $U$ Test was used to determine the difference in median of Vit D3 with Median of Serum ferritin in gender groups, and it was observed that no statistically significant difference was observed in gender groups for both the numerical variables under study, thus retain the null hypotheses. (Table-VII b)

\begin{tabular}{|c|c|c|c|c|c|}
\hline \multirow{2}{*}{\multicolumn{2}{|c|}{ Gender }} & \multicolumn{2}{|c|}{ Ferritin } & \multicolumn{2}{|c|}{ Vit D3 } \\
\hline & & Frequency & Percent & Frequency & Percent \\
\hline \multirow[b]{2}{*}{ Valid } & Male & 50 & 26.0 & 18 & 38.3 \\
\hline & Females & 142 & 74.0 & 29 & 61.7 \\
\hline
\end{tabular}




\begin{tabular}{|l|c|c|c|c|}
\hline \multicolumn{1}{|c|}{$N$} & Falid & Ferritin Level & Vit D3 Level & age \\
\hline & Missing & 192 & 47 & 192 \\
\hline Mean & & 0 & 145 & 0 \\
\hline Std. Error of Mean & 45.67 & 15.51 & .70 \\
\hline Median & 5.31 & 2.19 & 30.00 \\
\hline Mode & 11.93 & 11.10 & 30.00 \\
\hline Std. Deviation & 5.60 & 3.00 & 9.69 \\
\hline Range & 73.59 & 15.07 & 68.40 \\
\hline Minimum & 436.88 & 67.00 & 1.60 \\
\hline Maximum & 1.72 & 3.00 & 70.00 \\
\hline
\end{tabular}

Table-II. Descriptive statistics of Vit D3, Ferritin levels and age.

\begin{tabular}{|l|c|c|c|}
\hline & Frequency & Percent & Cumulative Percent \\
\hline Vit D3 <20ng/ml & 35 & 18.2 & 74.5 \\
\hline Vit D3 $(20.1-29.9) \mathrm{ng} / \mathrm{ml}$ & 7 & 3.6 & 89.4 \\
\hline Vit D3 $>30 \mathrm{ng} / \mathrm{ml}$ & 5 & 2.6 & 100.0 \\
\hline Total & 47 & 24.5 & \\
\hline System & 145 & 75.5 & \\
\hline Total & 192 & 100.0 & \\
\hline
\end{tabular}

Table-III. VIT D3 Categorization.

\begin{tabular}{|c|c|c|c|c|}
\hline \multicolumn{2}{|c|}{} & Frequency & Percent & Cumulative Percent \\
\cline { 2 - 5 } & Ferritin level less than $15 \mathrm{ng} / \mathrm{ml}$ & 118 & 61.5 & 61.5 \\
\cline { 2 - 5 } & Ferritin $>15 \mathrm{ng} / \mathrm{ml}$ & 74 & 38.5 & 100.0 \\
\hline
\end{tabular}

Table-IV. Ferritin categorization for Iron deficiency anemia as per WHO Guidelines.

\begin{tabular}{|c|c|c|c|}
\hline & & VIT D3 Level & Ferritin Level \\
\hline \multirow{3}{*}{ Vit D3 Level } & Pearson Correlation & 1 & $.822^{\star \star}$ \\
\hline & Sig. (2-tailed) & & .022 \\
\hline & $\mathrm{N}$ & 47 & 47 \\
\hline \multirow{3}{*}{ Ferritin Level } & Pearson Correlation & $.822^{\star \star}$ & 1 \\
\hline & Sig. (2-tailed) & .022 & \\
\hline & $\mathrm{N}$ & 47 & 192 \\
\hline
\end{tabular}

\begin{tabular}{|c|c|c|c|c|}
\hline & & & Vit D3 Catagories & Ferritin Catagories \\
\hline \multirow{6}{*}{ Spearman's rho } & \multirow{3}{*}{ Vit D3 Catagories } & Correlation Coefficient & 1.000 & $.744^{\star \star}$ \\
\hline & & Sig. (2-tailed) & . & .022 \\
\hline & & $\mathrm{N}$ & 47 & 47 \\
\hline & \multirow{3}{*}{ Ferritin Catagories } & Correlation Coefficient & $.744^{\star \star}$ & 1.000 \\
\hline & & Sig. (2-tailed) & .022 & . \\
\hline & & $\mathrm{N}$ & 47 & 192 \\
\hline
\end{tabular}

Table-VI. Spearman Correlations of VIT D Categories with Ferritin Categories. 


\begin{tabular}{|c|c|c|c|c|}
\hline \multicolumn{5}{|c|}{ Hypothesis Test Summary } \\
\hline & Null Hypothesis & Test & Sig. & Decision \\
\hline 1 & $\begin{array}{l}\text { The distribution of Vit D3 Level } \\
\text { the same across categories of } \\
\text { gender. }\end{array}$ & $\begin{array}{l}\text { Independent- } \\
\text { is Samples } \\
\text { Mann- } \\
\text { Whitney U } \\
\text { Test }\end{array}$ & .860 & $\begin{array}{l}\text { Retain the } \\
\text { null } \\
\text { hypothesis. }\end{array}$ \\
\hline 2 & $\begin{array}{l}\text { The distribution of Ferritin Level } \\
\text { the same across categories of } \\
\text { gender. }\end{array}$ & $\begin{array}{l}\text { Independent- } \\
\text { I isamples } \\
\text { Mann- } \\
\text { Whitney U } \\
\text { Test }\end{array}$ & .339 & $\begin{array}{l}\text { Retain the } \\
\text { null } \\
\text { hypothesis. }\end{array}$ \\
\hline
\end{tabular}

Asymptotic significances are displayed. The significance level is 05 .

Table-VII. Mann Whitney U Test for non-parametric variables.

\section{DISCUSSION}

Having read the importance of the both nutrients we are sure to have probably recorded the higher rate of Vit D3 deficiency and insufficiency in our target population i.e. $74.5 \%$ with Vit D3 level less than $20 \mathrm{ng} / \mathrm{ml}$. A study from Karachi reported that $76.2 \%$ of their study sampling ${ }^{16}$ had had deficiency that was matching our findings. Similarly it was higher than recorded in a study from Germany $(58 \%)^{17}$, however it was nearly similar to what have been reported from Scottish population $(78 \%) .{ }^{18}$ On the other hand the frequency of depleted or deficient than the required iron stores was recorded in our population as $61.5 \%$. Abuaisha $\mathrm{M}$ et $\mathrm{al}^{16}$ reported the prevalence of iron deficiency in $57.5 \%$ females at $95 \%$ confidence interval, and $7.6 \%$ in males that closely matching our findings. ${ }^{19}$

Globally the researchers are working on the association of Vit D3 with serum ferritn levels. ${ }^{20}$

Andıran and colleagues ${ }^{21}$ have reported a positive strong liner correlation of 25-Hydroxyvitamin $\mathrm{D}$ and serum ferritn levels in Korea and the US, population respectively. But Monlezun and colleagues $^{22}$ reported that the serum $25(\mathrm{OH})$ $D$ was not having any statistical relation in population of US and Portugal, respectively.

In present study using Person correlation test it was observed that a statistically significant strong uphill positive correlation exists between the levels of Vit D3 with Serum ferritin with $(p=0.022$, $r=0.7)$. Studies have reported that vitamin $D$ is inversely associated occurrence of IDA in women. Lee et $\mathrm{al}^{23}$, observed that the probability for iron deficiency anemia based on ferritin levels less than $12 \mathrm{ng} / \mathrm{ml}$, in patients with vitamin $D$ deficiency $[25(\mathrm{OH}) \mathrm{D}<15 \mathrm{ng} / \mathrm{ml}]$ was higher with an odds ratio of 1.86, that further increases to 2.59 (95\% $\mathrm{Cl}, 1.11-6.07)$ if we were able to control the other risk factors in healthy women of Korea, "what the authors claimed". ${ }^{23}$ Another study has reported that Vit D3 level were remarkably lower in patients with Iron deficiency anemia as compared to nonanemic patient based on serum ferritin level less than $12 \mathrm{ng} / \mathrm{ml}$ with a significant $\mathrm{p}$-value of $0.001 .^{24}$

In present study when we observed the same relation in the categories of Vit D3 \& Serum ferritin designed as per WHO guidelines ${ }^{16}$ we observed using spearman ranked correlation test, that a statistically significant strong uphill positive correlation was seen between the categories of Vit D3 with Categories of Serum ferritin with $(p=$ $0.022, r=0.7$ ).

Researchers have studied that there was a strong statistically positive correlation between the levels of ferritn and Vit $(44.05 \pm 25$. withnsion deficit disorders with vitamin $D(13.1 \pm 5.66$ vs. $32.9 \pm$ $9.12 \mathrm{ng} / \mathrm{ml})$ and serum ferritin of (15.76 \pm 18.06 vs. $98.2 \pm 52.37 \mathrm{ng} / \mathrm{ml}){ }^{25}$ Arabi $\mathrm{SM}$ et al also reported that supplementation with vitamin $D$ had significant effect on hemoglobin and ferritin levels along with effects on transferrin saturation. ${ }^{26} \mathrm{We}$ also observed using Mann Whitney $U$ Test on our skewed data to determine the difference in median of Vit D3 with Median of Serum ferritin in gender groups, and it was observed that no statistically significant difference was observed in gender groups for both the numerical variables under study, thus retain the null hypotheses. But Yoon $\mathrm{H}$ et al from the Korea have reported that serum vit D3 level had a negative association/ relation with the serum ferritin levels in male gender, but was positively related with serum ferritin levels in female gender. ${ }^{10}$ Munasinghe $\mathrm{LL}$ et al finding matched our resuts that Age, gender, income, ethnicity, blood pressure status, and serum total cholesterol were associated with serum ferritn and vit D3 levels but this association was not statistically significant. ${ }^{27}$

Regarding Vit D3 levels in gender groups Similarly 
Muscogiuri $\mathrm{G}^{28}$ have reported a higher rate of vitamin $D$ deficiency in male gender as compared to female gender ( $56 \%$ vs. $47 \%$; $p<0.001$ ). From these discussions we can admit a gender role in acquiring Vit D3 deficiency as apparently evident from our findings but not statistically significant at 95\% confidence interval. Some researcher have not find any gender preference like in present study and some have reported its high prevalence in female gender ${ }^{1}$ and some have reported its higher rate in male gender. ${ }^{28}$

Regarding ferritin we observed that 118 (61.5\%) were iron deficient(serum ferritin less than $15 \mathrm{ng} /$ $\mathrm{ml}$. Abuaisha $\mathrm{M}$ et $\mathrm{al}^{29}$ reported the prevalence of iron deficiency in $57.5 \%$ females at $95 \%$. Muscogiuri $\mathrm{G}^{28}$ published in Reprod Health reported that iron deficiency anemia (IDA) prevalent was $41 \%$ in antenatal women. ${ }^{28}$

\section{CONCLUSION}

It is concluded that the frequency of deficiency Vit D3 $<20 \mathrm{ng} / \mathrm{ml}$ in anemic patients was $74 \%$. The frequency of serum ferritin $<15 \mathrm{ng} / \mathrm{ml}$ in anemic patients was $61.5 \%$. There is a strong statistically significant correlation of Vit D3 with serum ferritin in anemic patients with $\mathrm{Hb}<11 \mathrm{~g} / \mathrm{dl}$. Therefore it is recommended that as IDA is more common in female gender therefore all the females attending the antenatal care services in tertiary and secondary care hospital with $\mathrm{Hb}$ less than $11 \mathrm{~g} / \mathrm{dl}$ must be screened for serum ferritin levels and Vit D3 levels and remedial action may be taken well in time.

\section{Copyright@ 25 July, 2020.}

\section{REFERENCES}

1. Holick MF (March). "High prevalence of vitamin D inadequacy and implications for health". Mayo Clinic Proceedings. 2006; 81 (3): 353-73.

2. Riaz H, Finlayson AE, Bashir S, Hussain S, Mahmood S, Malik F, Godman BP. Prevalence of Vitamin D deficiency in Pakistan and implications for the future. Expert Rev Clin Pharmacol. 2016; 9(2):329-38.

3. Jamila, Kian RA, Qamat T, Khan SA, Ahmed I et al. Biochemical analysis and frequency of Vitamin $D$ deficient people in different age and gender. J. Soc. Obstet. Gynaecol. Pak, 2018; 8(4):249-54.
4. Greene-Finestone LS, Berger C, de Groh M, Hanley DA, Hidiroglou N, Sarafin K, et al. 25-Hydroxyvitamin D in Canadian adults: Biological, environmental, and behavioral correlates. Osteoporosis international. 2011; 22(5):1389-99.

5. Gill TK, Hill CL, Shanahan EM, Taylor AW, Appleton SL, Grant JF, et al. Vitamin D levels in an Australian population. BMC public health. 2014; 14(1):1001.

6. Humayun Q, Iqbal R, Azam I, Khan AH, Siddiqui AR, Baig-Ansari N. Development and validation of sunlight exposure measurement questionnaire (SEM-Q) for use in adult population residing in Pakistan. BMC public health. 2012; 12:421.

7. Ku YC, Liu ME, Ku CS, Liu TY, Lin SL. Relationship between vitamin D deficiency and cardiovascular disease. World J Cardiol. 2013 26; 5(9):337-46.

8. Babaei M, Shafiei S, Bijani A, Heidari B, Hosseyni SR, Vakili Sadeghi M. Ability of serum ferritin to diagnose iron deficiency anemia in an elderly cohort. Rev Bras Hematol Hemoter. 2017; 39(3):223-8.

9. Guyatt $\mathrm{GH}$, Oxman AD, Ali M, Willan A, Mcllroy W, Patterson C. Laboratory diagnosis of iron-deficiency anemia. Journal of general internal medicine. 1992, 1; $7(2): 145-53$.

10. Yoon H, Bae NY, Gi MY, Park BY, Seong JM. The association between serum ferritin and 25-hydroxyvitamin $D$ and metabolic syndrome in Korean women: The Korea National Health and Nutrition Examination Survey 2010-2012. J Clin Biochem Nutr. 2017; 61(1): 60-6.

11. Jeong DW, Lee HW, Cho YH, Yi DW, Lee SY, Son SM, Kang $\mathrm{YH}$. Comparison of serum ferritin and vitamin d in association with the severity of nonalcoholic Fatty liver disease in Korean adults. Endocrinol Metab, $2014 ; 29(4): 479-88$.

12. Thomas CE, Guillet R, Queenan RA, Cooper EM, Kent $T R$, et al. Vitamin D status is inversely associated with anemia and serum erythropoietin during pregnancy. Am J Clin Nutr. 2015; 102(5):1088-95.

13. Eloqayli $H$, Al-Yousef $A$, Jaradat R. Vitamin D and ferritin correlation with chronic neck pain using standard statistics and a novel artificial neural network prediction model. $\mathrm{Br} \mathrm{J}$ Neurosurg. 2018; 32(2):172-176.

14. World Health Organization, WHO Report (1997). Family and reproductive health coverage of maternity care. Geneva, WHO: 205-220. 
15. World Health Organization and Centers for Disease Control and Prevention, Worldwide prevalence of anaemia 1993-2005: WHO global database on anaemia, B. de Benoist, E. McLean, E. Egli, and M. Cogeswell, Eds., WHO, 2018, http://www.who.int/vmnis/ publications/en/.

16. Mahmood K, Akhtar ST, Tali A, Haider I. Vitamin-D status in a Population of healthy adults in Pakistan. Pak Jour Med Sci, 2009; 25(4):545-50.

17. Hintzpeter B, Mensink GB, Thierfelder W, Müller MJ, Scheidt-Nave C. Vitamin D status and health correlates among German adults. Eur J Clin Nutr. 2008; 62(9):1079-89.

18. Zgaga L, Theodoratou E, Farrington SM, Agakov F, Tenesa A, Walker $M$ et al. Diet, environmental factors, and lifestyle underlie the high prevalence of vitamin D deficiency in healthy adults in Scotland, and supplementation reduces the proportion that are severely deficient. J Nutr. 2011; 141(8):1535-42.

19. Abuaisha M, Itani H, El Masri R, Antoun J. Prevalence of Iron Deficiency (ID) without anemia in the general population presenting to primary care clinics: a cross-sectional study. Postgrad Med. 2020; 22:1-6.

20. Tharwat RJ, Balilah S, Habib HM, Mahmoud NH, Beek FS, Almadani FK, et al. Ferritin and Vitamin D levels and its relation to bone diseases in thalassemic adults: A hospital based retrospective cohort study. J Appl Hematol, 2019; 10:15-22.

21. Andıran N, Çelik N, Akça H, Doğan G. Vitamin D deficiency in children and adolescents. Journal of clinical research in pediatric endocrinology. 2012 Mar;4(1):25.

22. Castro FD, Magalhães J, Carvalho PB, Moreira MJ, Mota P, COTTER J. Lower levels of vitamin D correlate with clinical disease activity and quality of life in inflammatory bowel disease. Arquivos de Gastroenterologia. 2015 Dec;52(4):260-5.
23. Lee JA, Hwang JS, Hwang IT, Kim DH, Seo JH, Lim JS. Low vitamin $D$ levels are associated with both iron deficiency and anemia in children and adolescents. Pediatr Hematol Oncol. 2015; 32(2):99-108.

24. Suh YJ, Lee JE, Lee DH, Yi HG, Lee MH, Kim CS, Nah JW, Kim SK. Prevalence and relationships of iron deficiency anemia with blood cadmium and Vitamin D Levels in Korean Women. J Korean Med Sci. 2016; 31(1):25-32.

25. Hassan FM, Soliman MA, Abd El-Nabi SA, Elgazzar GA. Relationship between serum vitamin D and iron level in children with attention-deficit hyperactivity disorder. Menoufia Med J 2018; 31:999-1004.

26. Arabi SM., Ranjbar G., Bahrami, LS. The effect of vitamin D supplementation on hemoglobin concentration: A systematic review and meta-analysis. Nutr J 2020; 19: 11. https://doi.org/10.1186/s12937-020-0526-3.

27. Munasinghe LL, Ekwaru JP,. Mastroeni MF, Mastroeni SS, Veugelers PJ. The association of serum 25-hydroxyvitamin D concentrations with elevated serum ferritin levels in normal weight, overweight and obese Canadians. PLoS One. 2019; 14(3): e0213260.

28. Muscogiuri G, Barrea L, Somma CD, Laudisio D, Salzano C. Sex differences of Vitamin D status across BMI Classes: An observational prospective cohort study. Nutrients 2019; 11,3034-46 doi:10.3390/nu11123034.

29. Abuaisha M, Itani H, El Masri R, Antoun J. Prevalence of Iron Deficiency (ID) without anemia in the general population presenting to primary care clinics: A cross-sectional study. Postgrad Med. 2020; 22:1-6.

\begin{tabular}{l} 
AUTHORSHIP AND CONTRIBUTION DECLARATION \\
\begin{tabular}{|c|c|c|c|}
\hline Sr. \# & Author(s) Full Name & \multicolumn{1}{|c|}{ Contribution to the paper } & Author(s) Signature \\
\hline 1 & Hamzullah Khan & $\begin{array}{l}\text { Paper design, concept, data } \\
\text { collection, analysis, writing the } \\
\text { manuscript. } \\
\text { Data collection, critical review. }\end{array}$ \\
\hline 2 & Mohammad Basharat &
\end{tabular} \\
\hline
\end{tabular}

